\title{
Evaluation of Serum Nitric Oxide Level and its Relationship with Disease Activity Parameters in Patients with Rheumatoid Arthritis
}

\section{Romatoid Artritli Hastalarda Serum Nitrik Oksit Seviyesinin ve Hastalık Aktivite Parametreleri ile İlişkisinin Değerlendirilmesi}

\author{
-Hülya Deveci', @Zeliha Cansel Özmen² \\ 'Tokat Gaziosmanpasa University, School of Medicine, Department of Physical Medicine and Rehabilitation, Tokat, Turkey \\ ${ }^{2}$ Tokat Gaziosmanpasa University, School of Medicine, Department of Clinical Biochemistry, Tokat, Turkey
}

\begin{abstract}
Aim: Nitric oxide (NO) is a molecule known to play a role in many physiological and pathological events in the body. It is thought to play an active role in inflammation. Rheumatoid arthritis (RA) is the most common chronic inflammatory autoimmune disease worldwide. In this study, we aimed to evaluate the serum NO levels of RA patients and their relation with parameters that are indicators of disease activity.
\end{abstract}

Material and Method: Thirty patients with RA (7 males/ 23 females, mean age $48.80 \pm 7.88$ years old) and 30 healthy control groups were included in the study. Both groups were compared with erythrocyte sedimentation rate (ESR), C-reactive protein (CRP), rheumatoid factor (RF), anti cyclic citrullinated peptide antibody (anti CCP) and serum NO levels and clinically with Visual Analog Scale (VAS), Disease Activity Score-28 (DAS-28) and Health Assessment Questionnaire (HAQ) scales.

Results: ESR, CRP and NO levels in the patient group were significantly higher than the control group $(p<0.05)$. When the patient group was classified as active and inactive group (active disease: DAS-28>3.2, inactive disease DAS-28<3.2) according to DAS-28 scores, there was no significant difference in serum NO levels between the two groups. Serum NO levels of the patient group were not correlated with clinical (VAS, DAS-28) and laboratory markers (ESR, CRP, RF, Anti CCP) of disease activity.

Conclusion: In this study, we found that serum NO levels in RA patients increased significantly compared to the healthy control group. However, increased serum NO levels in RA patients were not associated with laboratory and clinical disease activity parameters.

Keywords: Nitric oxide, rheumatoid arthritis, disease activity score-28 (DAS-28), health assessment questionnaire (HAQ)

\section{Öz}

Amaç: Nitrik oksit (NO), vücutta çok sayıda fizyolojik ve patolojik olayda rol oynadığı bilinen bir moleküldür. Inflamasyonda da etkin rolü olduğu düşünülmektedir. Romatoid artrit (RA) ise dünya genelinde en sık görülen kronik enflamatuar otoimmun hastalıktır. Bu çalışmada RA hastalarının serum NO düzeylerini ve bunun hastalık aktivite göstergesi olan parametrelerle ilişkisini değerlendirmeyi amaçladık.

Gereç ve Yöntem: Çalışmaya RA tanılı 30 hasta (7 erkek ve 23 kadın,

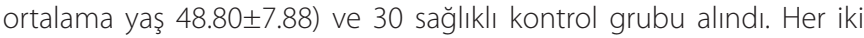
grubun laboratuar olarak eritrosit sedimentasyon hız (ESR), C-reaktif protein (CRP), romatoid faktör (RF), anti siklik sitrullin peptid antikoru (Anti CCP) ve serum NO düzeyleri ile klinik olarak Vizuel Analog Skalası (VAS), Hastalık Aktivite Skoru-28 (DAS-28) ve Sağlık Değerlendirme Anketi (HAQ) ölçekleri ile karşılaştırmaları yapıldı.

Bulgular: Hasta grubundaki ESR, CRP ve NO düzeyleri kontrol grubundan anlamlı düzeyde yüksekti $(p<0.05)$. Hasta grubu DAS-28 skorlarına göre aktif ve inaktif grup (aktif hastalık:DAS-28>3.2, inaktif hastalık DAS-28<3.2) olarak sınıflandııldığında her iki grup arasında serum NO düzeyleri açısından anlamlı fark yoktu. Hasta grubunun serum NO düzeyleri ile hastalık aktivitesinin klinik (VAS, DAS-28) ve laboratuvar belirteçleri (ESR, CRP, RF, Anti CCP) arasında korelasyon gözlenmedi.

Sonuç: Bu çalışmada RA hastalarında serum NO düzeylerinin sağlıklı kontrol grubuna göre anlamlı olarak arttığını bulduk. Bununla birlikte, RA hastalarında artmış serum NO seviyeleri, hastalık aktivitesinin klinik ve laboratuar parametreleri ile ilişkili değildi.

Anahtar Kelimeler: Nitrik oksit, romatoid artrit, DAS-28, HAQ

Corresponding (IIletişim): Hülya Deveci, Tokat Gaziosmanpasa University, School of Medicine, Department of Physical Medicine and Rehabilitation, Tokat, Turkey

E-mail (E-posta): hulyadeveci.1977@ gmail.com

Received (Geliş Tarihi): 14.07.2020 Accepted (Kabul Tarihi): 17.08.2020 


\section{INTRODUCTION}

Rheumatoid arthritis (RA) is the most common chronic autoimmune inflammatory rheumatic disease worldwide, but there are still unknown points in its pathogenesis. Although the pathogenetic mechanism that initiated the disease is not clear, overproduction of nitric oxide (NO) is closely related to the development of RA. ${ }^{[1]}$ Pathologically, inflammatory mediators such as NO, interleukin-6, and tumor necrosis factor-a in rheumatoid joints exacerbate inflammation. ${ }^{[2,3]}$

Nitric oxide is an intracellular and transcellular signal molecule that is synthesized from $\mathrm{L}$-arginine via the nitric oxide synthase (NOS) enzyme. ${ }^{[4]}$ The NO formed is an unstable molecule and quickly turns into more stable and inactive nitrite and nitrate. Since these molecules are in liquid phase, they can be used as an indicator of NO production in biological fluids. In addition, NO turns into peroxynitrite, which is a strong oxidant that causes tissue destruction. ${ }^{[5]}$ The NOS enzyme has 2 isotypes, namely 'constitutive NOS' (cNOS), which are found structurally at the basal level in cells, and 'inducible NOS' (iNOS), which are activated after biochemical stimulation. cNOS also has 2 isotypes: 'endothelial NOS' (eNOS) and 'neuronal NOS' (nNOS). cNOS is constantly secreted by the vascular endothelium at the physiological level. ${ }^{[6]} \mathrm{NO}$ synthesis can be prevented by inhibition of the NOS enzyme. NO modulates a wide range of physiological and pathophysiological conditions. In physiological conditions, while it exhibits features such as vascular tone regulation, anti-inflammatory effect, anti-tumor effect and wound-healing effect, pathologically high NO levels act as proinflammatory mediators for tissue destruction and apoptosis. ${ }^{[7,8]}$ Prolonged high NO levels can cause serious chronic inflammatory disorders, including RA, systemic lupus erythematosus, inflammatory bowel disease and sepsis. ${ }^{[8-10]}$

Although NO has been the subject of many studies since its definition, its role in inflammatory diseases remains uncertain. Several studies have found a notable role of NO during the development and progression of RA. ${ }^{[11-13]}$ Some researchers have shown that high NO concentrations (systemic and intra articular) can contribute to arthritis in experimental animal models and patients. ${ }^{[14]}$ Besides the uncertain points in the pathogenesis of RA, laboratory and clinical parameters used to monitor disease activity may be insufficient in some cases. On the other hand, despite the recent developments in treatment in the last 20 years, some of the patients are still not able to fully remission. Research on the contribution of NO to the pathogenesis, its relationship with disease activity and whether it will be a target for treatment is ongoing. ${ }^{[8]}$

In this study, we aimed to evaluate the serum NO levels in patients with RA by comparing them with the healthy control group and to investigate their relationship with disease activity.

\section{MATERIAIL AND METHOD}

This cros-sectional observational study was conducted with 30 RA patients ( 7 males, 23 females, mean age $48.80 \pm 7.88$ years old) and 30 healthy control participants. The age and gender averages were similar in the groups. Patients between 40-60 years old who were diagnosed with RA according to ACR 2010 criteria were included in the study. Patients with inflammatory rheumatic disease other than RA, systemic diseases such as hypertension and diabetes mellitus, those with active infection and malignancy during the study, patients who used anticytokine agents (such as antitumor necrosis factor drug therapy) or more than $10 \mathrm{mg}$ of prednisolone in the last six months were excluded from the study. Patients using conventional disease modifying antirheumatic drugs (DMARD) such as methotrexate, sulfasalazine were not excluded. In addition, patients with drug and food use that affect NO levels were also excluded. The healthy control group was consisted of hospital workers without systemic and chronic diseases. This research study was approved by the institutional clinical ethics committee (20-KAEK-203) and it was planned and conducted in accordance with the provisions of the Helsinki Declaration. The aims of the study were explained in detail to all participants and signed consent forms were taken.

Detailed examinations of the patients were done by the same researcher. Age, gender, duration of illness, duration of morning stiffness, drugs used were recorded. The basic demographic, clinical and laboratory features of the groups are shown in Table 1. Disease activity was evaluated by clinical evaluation scales Visual Analog Scale (VAS), Disease Activity Score-28 (DAS-28). Quality of life assessment was done with Health Assessment Questionnaire (HAQ), a RA-specific quality of life assessment scale. In the laboratory evaluation of the disease activity, erythrocyte sedimentation rate (ESR), C-reactive protein (CRP), rheumatoid factor (RF), anti cyclic citrullinated peptide antibody (anti CCP) were used.

\begin{tabular}{|c|c|c|c|}
\hline & Control Group & RA group & $P$ value \\
\hline $\mathrm{N}$ & 30 & 30 & \\
\hline Age, years (mean $\pm S D$ ) & $44.83 \pm 4.76$ & $48.80 \pm 7.88$ & $>0.05$ \\
\hline Sex (male/female) & $11 / 19$ & $7 / 23$ & $>0.05$ \\
\hline Disease duration (year) & NA & $10(2-35)$ & \\
\hline VAS (mean $\pm S D$ ) & NA & $50(0-90)$ & \\
\hline DAS-28 (mean $\pm S D)$ & NA & $2.95 \pm 1.29$ & \\
\hline $\mathrm{HAQ}$ & NA & $0.17(0-1.8)$ & \\
\hline Positivity of RF, n (\%) & - & $20(66.66)$ & \\
\hline $\begin{array}{l}\text { Positivity of Anti CCP, } \\
\mathrm{n}(\%)\end{array}$ & - & $23(76.66)$ & \\
\hline $\begin{array}{l}\operatorname{ESR}(\mathrm{mm} / \mathrm{h})[\text { median } \\
(\min .-\mathrm{max} .)]\end{array}$ & $11(2-22)$ & $20(4-79)$ & $<0.001^{*}$ \\
\hline $\begin{array}{l}\operatorname{CRP}(\mathrm{mg} / \mathrm{dl}) \text { [median } \\
\text { (min.-max.)] }\end{array}$ & $1.10(0.20-3.60)$ & $5.05(0.80-13.6)$ & $<0.0001^{*}$ \\
\hline $\mathrm{NO}(\mu \mathrm{mol} / \mathrm{L})$ & $253.6 \pm 49.9$ & $305.6 \pm 50.1^{*}$ & $<0.0001^{*}$ \\
\hline \multicolumn{4}{|c|}{$\begin{array}{l}\text { NA:Not applicable; VAS:Visual analog scale; DAS-28: } 28 \text {-joint Disease Activity Score; HAQ: Health } \\
\text { Assessment Questionnaire; RF: Rheumatoid factor; Anti CCP:Anticitrullinated peptide antibody; ESR: } \\
\text { Erythrocyte sedimentation rate; CRP:C-reactive protein; NO:Nitric oxide } \\
\text { *Significantly different from control grup at } p<0.05 \text { level. }\end{array}$} \\
\hline
\end{tabular}


Visual analog scale is the most widely used and easy to use scale for assessing pain. The patient is asked to rate the pain on this line by scoring between 0 and 10 as " $0=$ no pain" and "10 = worst pain imaginable" on a horizontal $10 \mathrm{~cm}$ line. DAS-28 score is a widely used scale for evaluating disease activity. It was calculated by the number of swollen joints, the number of sensitive joints, ESR and VAS values. DAS-28<3.2 was considered low disease activity. Health Assessment Questionnaire (HAQ) has been developed to evaluate the functional status in rheumatic diseases. It contains eight items consisting of 20 questions. It has been shown to correlate with disease activity indicators.

For evaluation of serum NO level, venous blood was centrifuged at $3000 \mathrm{rpm}$ for 15 minutes immediately after collection and stored at -80 degrees before use. Serum $\mathrm{NO}$ levels were measured after collecting the blood of all participants in the patient and control groups. The serum NO level was assessed by measuring the serum nitrite and nitrate, because the half-life of NO is very short, and it quickly breaks down in to nitrite $\left(\mathrm{NO}_{2}\right)$ and nitrate $\left(\mathrm{NO}_{3}\right)$ products. The $\mathrm{NO}_{2}$ and $\mathrm{NO}_{3}$ levels were measured by using the Griess reaction. ${ }^{[15]}$ In this method, the blood samples were first deproteinized with Somogyi's reagent; then, the total $\mathrm{NO}_{2}$ level was measured using a spectrophotometer at $545 \mathrm{~nm}$ after the conversion of $\mathrm{NO}_{3}$ to $\mathrm{NO}_{2}$ by copperized cadmium granules. Afterward, a standard curve was established using a set of serial dilutions (10-8-10-3 mol/l) of sodium nitrite. A linear regression was established using the peak area from the the $\mathrm{NO}_{2}$ standards. The resulting equation was used to calculate the unknown sample concentrations, and the results were expressed in micromoles per liter of plasma ( $\mathrm{mmol} / \mathrm{l})$.

\section{Statistical Analysis}

The data were presented as the mean \pm standard error or median (minimum-maximum). The categorical variables were compared using the chi-squared test, and the contininous variables were analyzed using an analysis of variance, Student's t-test and Mann-Whitney $U$ test. Spearman's correlation coefficient was used to test the correlations between two variables. All of the analyses were performed using the Statistical Package for the Social Sciences version 18.0 (SPSS Inc., Chicago, IL, USA) and Graph Pad 5 software. Differences of $\mathrm{P}<0.05$ were considered to be statistically significant.

\section{RESULTS}

The demographic, clinical and laboratory data of the groups are reported in Table 1. There were no significant differences with regard to the age or gender distribution $(P>0.05)$. ESR levels in the RA group were significantly higher than the control group. [20 (4-79) and $11(2-22)$, respectively] $(p<0.001)$. Similarly, in the RA group serum CRP levels were also significantly higher than the control group [5.05 (0.80-13.6) and 1.10 (0.20-3.60), respectively] $(p<0.0001)$. RF was positive in $66.6 \%$ and anti CCP in $76.6 \%$ of the patients in the RA group. Mean serum NO concentrations in the patient group and control group were $305.6 \pm 50.1$ and $253.6 \pm 49.9 \mu \mathrm{mol} / \mathrm{L}$, respectively (Figure 1). There was a statistically significant difference between the two groups $(p<0.0001)$. When RA patients were divided into two groups as active and inactive (DAS $28>3.2$ and DAS $28<3.2$, respectively), no significant difference was found between NO levels ( $p>0.05)$.

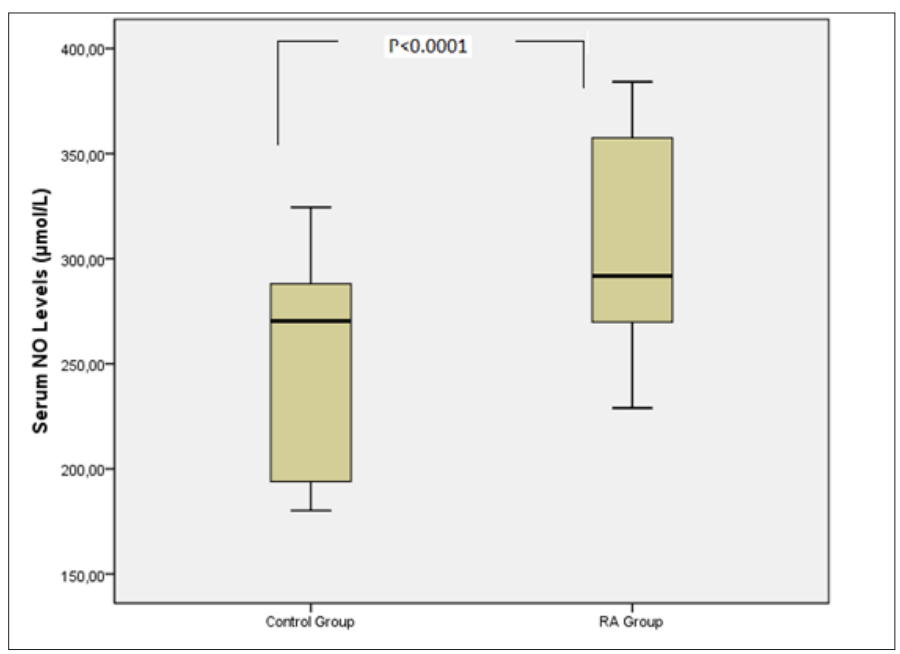

Figure 1. Mean serum nitrate concentration of patient and control groups

The median VAS score in the RA group was $50 \mathrm{~mm}$ (0-90), the mean DAS-28 score was $2.95 \pm 1.29$, and the median HAQ score was 0.17 (0-1.8).

Serum NO levels were not correlated with clinical markers of the disease activity (VAS, DAS 28) and laboratory markers (ESR, CRP, RF, Anti CCP). In addition, serum NO levels were not correlated with RA-specific quality of life scale HAQ (Table2).

Table 2. Correlation between clinical, laboratory data and serum nitric oxide level in the rheumatoid arthritis group

\begin{tabular}{lcc} 
& \multicolumn{2}{c}{ NO } \\
& $\mathrm{R}^{2}$ & P value $^{\mathrm{a}}$ \\
\hline DAS-28 & -0.175 & 0.354 \\
VAS & -0.224 & 0.252 \\
HAQ & -0.110 & 0.564 \\
ESR & -0.037 & 0.845 \\
CRP & 0.218 & 0.247 \\
RF & 0.125 & 0.482 \\
Anti CCP & -0.074 & 0.713 \\
\hline NO:Nitric oxide; DAS-28: Disease Activity Score 28 joint; VAS:Visual Analog Scale; HAQ: Health \\
Assessment Questionnaire; ESR: Erythrocyte Sedimentation Rate; CRP: C-Reactive Protein; \\
RF: Rheumatoid factor; Anti CCP: Anti Citrullinated Peptide Antibody
\end{tabular}

\section{DISCUSSION}

In our study, in which we compared serum NO levels with healthy control group in patients with rheumatoid arthritis, the serum nitric oxide level of the patient group was significantly high. However, serum nitric oxide level was not associated with clinical and laboratory disease activity markers. 
Increased endogenous NO synthesis has been demonstrated in RA, suggesting that overproduction of NO may be important in the pathogenesis of RA. In many studies, the inflamed joint in RA is the dominant NO source. ${ }^{[13,16]}$ In support of this situation, in our study, serum NO levels were significantly higher in the patient group than in the healthy control group. Although NO plays a central role in many physiological processes, its increased production is pathological. The effects of NO depend on its concentration. Although NO is known to mediate many different cell functions in the area of synovial inflammation such as cytokine production, signal transduction, mitochondrial functions, and apoptosis, its basic mechanisms in inflammatory diseases remain uncertain. ${ }^{[17]}$

There is a lot of evidence that NO is involved in tissue damage in inflammatory and autoimmune diseases. ${ }^{[9,18]}$ NO reacts with locally synthesized superoxide anions, leading to the formation of reactive superoxide anions, causing tissue damage. ${ }^{[6]}$ The damage from NO released from activated macrophages and endothelial cells in the target cell was confirmed as invitro. ${ }^{[19]}$ On the other hand, the contribution of iNOS to oxidative / nitrative stress is well documented in inflamed joints. ${ }^{[20]}$ iNOS is expressed in inflamed tissue and there is a correlation between disease activity and iNOS expression. ${ }^{[21]}$ Also, in animal models, inflammation can be suppressed with iNOS inhibitors. ${ }^{[22]}$ Today, it is thought that with the inhibition of NOS, a new therapeutic approach can be developed in the treatment of chronic autoimmune diseases. The studies related to NO in recent years have evolved in this direction. ${ }^{\left[{ }^{9]}\right.}$ Another mechanism of NO's damage in tissues is through $T$ cells. NO has been shown to regulate $T$ cell functions under physiological conditions, but recent evidence suggests that overproduction of $\mathrm{NO}$ contributes to $\mathrm{T}$ cell dysfunction in RA. ${ }^{[9]}$ With the data collected to date, it has been observed that the effects of NO are complex, diverse and sometimes antagonistic. ${ }^{[17]}$ The basic mechanisms of NO's influence are not fully understood and remain a rich area to be investigated.

There are contradictory studies on the relationship between RA and NO in the literature. In two separate studies by Ali et al. ${ }^{[1]]}$ and Khallaf et al. ${ }^{[23]}$ increased serum NO levels were detected in the serum of patients with RA, and it was stated that NO was significantly associated with disease activity, inflammatory markers and radiological joint status. Similarly, there are other studies in RA where serum NO levels are high and correlated with disease activity parameters. ${ }^{[13,24-27]}$ In another study by Choi, similar to the results of our study, NO production was significantly increased in patients with RA, but serum NO concentration was not associated with RA's disease activity assessed by CRP, ESR and RF. ${ }^{[28]}$ In our study, although serum NO levels were significantly higher in RA patients compared to the control group, it was not related to both laboratory parameters of the disease activity (ESR, CRP, RF, Anti CCP) and clinical (DAS-28) parameters. This may have been due to the low number of patients and the low average disease activity in the patient group. Similar to our study, Güzel et al. ${ }^{[29]}$ did not find that serum NO levels were associated with disease activity evaluated with DAS 28 in RA patients, but found that NO levels in synovial fluid were associated with disease activity. In the in vitro experimental study of Nagy et al..$^{[30]}$ no relationship was found between NO production and disease activity assessed with DAS 28.

The most important limitation of our study is the small number of patients. Further studies are needed on this subject with larger patient numbers and well-homogenized patient groups. Studies on NOS inhibition in the treatment of RA, especially in recent years, are remarkable. Therefore, studies on the relationship between RA and NO are important in that they constitute a step for future studies on possible future treatment agents of RA, whose effective treatment is still a problem today.

\section{CONCLUSION}

In studies performed to date, serum NO increase in RA patients is clear. However, the results of studies on the ways in which NO effects pathogenesis and whether it is related to disease activity are contradictory. To clarify this issue, new research is needed with more patient numbers and more homogeneous patient groups.

\section{ETHICAL DECLARATIONS}

Informed Consent: Written informed consent was obtained from all participants who participated in this study.

Conflict of Interest Statement: The authors have no conflicts of interest to declare.

Financial Disclosure: The authors declared that this study has received no financial support.

Author Contributions: All of the authors declare that they have all participated in the design, execution, and analysis of the paper, and that they have approved the final version.

Ethical Issue: Ethics committee permit for the study was obtained from the Clinical Research Ethics Committee of Tokat Gaziosmanpaşa University with the decision numbered 20KAEK-203.

\section{REFERENCES}

1. van't Hof RJ, Hocking L, Wright PK, Ralston SH. Nitric oxide is a mediator of apoptosis in the rheumatoid joint. Rheumatology 2000;39(9):1004-8.

2. Headland SE, Jones HR, Norling LV, et al. Neutrophil-derived microvesicles enter cartilage and protect the joint in inflammatory arthritis. Sci Transl Med 2015;25:7(315):315ra190.

3. Zhang Q, Dehaini D, Zhang Y, et al. Neutrophil membrane-coated nanoparticles inhibit synovial inflammation and alleviate joint damage in inflammatory arthritis. Nanotechnol 2018;13(12):1182-90.

4. Nathan C, Xie QW. Regulation of biosynthesis of nitric oxide. J Biol Chem 1994;269:13725-8.

5. Nathan C, Xie QW. Nitric oxide synthesis: roles, tolls and controls. Cell 1994;78:915-8.

6. Moncada S, Palmer RM, HiggsEA. Nitric oxide: Physiology, pathophysiology and pharmacology. Pharmol Rev 1991;43:109-42. 
7. Beltrán B, Mathur A, Duchen MR, Erusalimsky JD, Moncada S. The effect of nitric oxide on cell respiration: a key to understanding its role in cell survival or death. Proc Natl Acad Sci USA 2000;97:14602-7.

8. Yeo J, Lee YM, Lee J,et al. Nitric oxide-scavenging nanogel for treating rheumatoid arthritis. Nano Lett 2019;19(10):6716-24.

9. Nagy G, Koncz A, Telarico T, et al. Central role of nitric oxide in the pathogenesis of rheumatoid arthritis and systemic lupus erythematosus. Arthritis Res Ther 2010;12(3):210.

10. Kolios G, Valatas V, Ward SG. Nitric oxide in inflammatory bowel disease: a universal Messenger in an unsolved puzzle. Immunology 2004;113(4):427-37.

11. Ali AM, Habeeb RA, El-Azizi NO, Khattab DA, Abo-Shady RA, Elkabarity RH. Higher nitric oxide levels are associated with disease activity inEgyptian rheumatoid arthritis patients. Rev Bras Reumatol 2014;54(6):446-51.

12. Mazzetti B, Grigolo L, Pulsatelli P,et al. Differential roles of nitric oxide and oxygen radicals in chondrocytes affected by osteoarthritis and rheumatoid arthritis. Clin Sci (Lond.) 2001;101(6):593-9.

13. Pham TN, Rahman P, Tobin YM, et al. Elevated serum nitric oxide levels in patients with inflammatory arthritis associated with co-expression of inducible nitric oxide synthase and protein kinase C-eta in peripheral blood monocyte-derived macrophages. J Rheumatol 2003;30:2529-34.

14. Stichtenoth DO, Frolich JC. Nitric oxide and inflammatory joint diseases. Br J Rheumatol 1998;37:246-57.

15. Cortas NK, Wakid NW. Determination of inorganic nitrate in serum and urine by a kinetic cadmium-reduction method. Clin Chem 1990;36(8):1440-43.

16. Farrell AJ, DR, Palmar RMJ. Increased concentrations of nitrite in synovial fl uid and serum samples suggest increased nitric oxide synthesis in rheumatic diseases. Ann Rheum Dis 1992;51:1219-22.

17. Spiller F, Oliveira Formiga R, Fernandes da Silva Coimbra J, Alves-Filho JC, Cunha TM, Cunha FQ. Targeting nitric oxide as a key modulator of sepsis, arthritis and pain. Nitric Oxide 2019;1:89:32-40.

18. Laskin DL, Heck DE, Laskin JD. Role of inflammatory cytokines and nitric oxide in hepatic and pulmonary toxicity. Toxicology Letters 1998;102:28993.

19. Kolb H, Kolb-Bachofen V. Nitric oxide in autoimmune disease: Cytotoxic or regulatory mediator? Immunol Today 1998;19: 556-61.

20. Al-Nimer MSM, Al-Obaidi SAH, Al-Dulaimi KS. Serum nitric oxide and peroxynitrite levels in adult sero-positive rheumatoid arthritis treated with disease modifying antirheumatic drugs: a preliminary report. Turk J Med Sci 2010;40(2):191-7.

21. Nathan C. Indicuble nitric oxide synthase: What difference does it make? J Clin Invest 1997;100:2417-23.

22. McCartney-francis N, Allen BJ, Mizel DE: Suppression of arthritis by an inhibitor of nitrice oxide synthase. J Exp Med 1993;178:749-54.

23. Khallaf HA, Nosair NAA, Alashkar DS, Abdella DHM. Assessment of serum nitrite level in patients with rheumatoid arthritis. Tanta Med J 2016;44(1):12.

24. Taysi S, Umudum Z, Sari RA, Kuskay S, Bakan N. Nitric oxide level and superoxide dismutase activity in serum of patients with rheumatoid arthritis. The Pain Clinic 2003;15(4):429-34.

25. Ersoy Y, Ozerol E, Baysal O, et al. Serum nitrate and nitrite levels in patients with rheumatoid arthritis, ankylosing spondylitis, and osteoarthritis. Ann Rheum Dis 2002;61(1):76-8.

26. Veselinovic $M$, Barudzic N, Vuletic $M$, et al. Oxidative stress in rheumatoid arthritis patients: relationship to diseases activity. Mol Cell Biochem 2014; 391:225-32.

27. Onur O, Akinci AS, Akbiyik F, Unsal I. Elevated levels of nitrate in rheumatoid arthritis. Rheumatol Int 2001;20:154-8.

28. Choi JW. Nitric oxide production is increased in patients with rheumatoid arthritis but does not correlate with laboratory parameters of disease activity. Clin Chim Acta 2003;336:83-7.
29. Güzel S, Seven A, Güzel EC, Hamuryudan V. Nitric oxide and superoxide dismutase in rheumatoid arthritis: correlation with disease activity. Turkish J Family Med Primary Care 2012; 6:7-12.

30. Nagy G, Clark JM, Buzas E, et al. Nitric oxide production of T lymphocytes is increased in rheumatoid arthritis. Immunol Lett 2008;118(1):55-8. 